\title{
Religious affect and personal happiness: A replication among Sunni students in Malaysia
}

\section{Mustafa Tekke}

Duzce University, Duzce, Turkey

\section{Leslie J. Francis ${ }^{*}$}

University of Warwick, Coventry, England, UK

\section{Mandy Robbins}

Wrexham Glyndwr University, Wrexham, Wales, UK

Corresponding author:

\section{Leslie J. Francis}

Warwick Religions \& Education Research Unit

Centre for Education Studies

The University of Warwick

Coventry CV4 7AL United Kingdom

Tel: +44 (0)24 76522539

Fax: +44 (0)247657 2638

Email: leslie.francis@warwick.ac.uk

\section{Abstract}

Building on earlier studies conducted in Christian, Jewish, and Islamic contexts, this study tests the hypothesis that higher levels of positive religious affect are associated with higher levels of personal happiness among a sample of 189 Sunni Muslim students studying at the International Islamic University in Malaysia; participants completed the Sahin-Francis Scale of Attitude toward Islam, the Oxford Happiness Inventory, and the short-form Eysenck Personality Questionnaire Revised. The data reported a small but statistically significant association between 
religiosity and happiness after taking sex and individual differences in personality into account.

Keywords: Religion, happiness, personality, psychology, Malaysia, Oxford Happiness Inventory.

This study tests the hypothesis that higher levels of positive religious affect are associated with higher levels of personal happiness. The Islamic tradition envisages a close connection between religious commitment and human flourishing in general and with human wellbeing and happiness in particular. Qur'anic verses, such as "For those who believe and do righteous deeds-for them is happiness and a beautiful return" (Rad 13, 29), and "As for those who are happy, they will be in Paradise, remaining therein for as long as the heavens and the earth endure, except as your Lord wills-a reward without end" (Hud $11,108)$ reflect claims consistent with those made within other Abrahamic religious traditions.

Within the Jewish scriptures the Book of Psalms proclaims 'Happy are those who do not follow the advice of the wicked, or take the path that sinners tread' (Psalm 1: 1), and 'Happy is everyone who fears the Lord, who walks in his ways. You shall eat the fruit of the labour of your hands; you shall be happy, and it shall go well with you' (Psalm 128: 1-2). The Book of Proverbs proclaims, 'Happy are those who trust in the Lord' (Proverbs 16: 20), and 'Happy are those who keep the law of the Lord' (Proverbs 29: 18).

Within the Christian scripture, in the Sermon on the Mount Jesus proclaims, 'Happy are the peacemakers for they will be called the children of God' (Matthew 5:9) and elsewhere Jesus says 'Happy are those who hear the word of God and obey it' (Luke 11:28). Saint Paul, writing to Romans, states 'Happy are those whose iniquities are forgiven, and whose sins are covered' (Romans 4:7). It is claims of this nature, concerning the connection between religion and happiness that are of perennial interest in empirical theology and in the empirical psychology of religion (see Atherton, Graham, \& Steedman, 2011).

The results of empirical studies in this field, however, are still inconclusive or ambiguous. Reviewing the state of the empirical evidence more than 20 years ago, Robbins and Francis (1996) concluded that the problem was, at least in part, a consequence of the wide range of ways in which both religion and happiness have been conceptualized and operationalized in the literature. Responding to this possibility, Robbins and Francis (1996) proposed a research strategy based on painstaking replication by studies using common measures of religion and common measures of happiness, conducted in different populations. In some ways this has been seen as an unfashionable approach within the peer-review literature where a stronger emphasis may be placed on originality than on replication. The importance of careful replication has, however, been 
reestablished as a priority within psychology by the well-publicized Replication Project (see Fradera, 2015). Robbins and Francis (1996) made three specific recommendations for a research strategy involving a series of coordinated studies: the measurement of religion, the measurement of happiness, and the inclusion of a key set of control variables. Several studies within Christian and Jewish contexts have responded to the invitation to work with these recommendations, and just one recent study has done so within an Islamic context (Francis, Ok, \& Robbins, 2017). The aim of the present study is to extend the reach of this research program within a second Islamic context.

\section{Religious affect}

First, Robbins and Francis (1996) proposed establishing a set of studies exploring the connection between religion and happiness grounded in the measurement of religious affect, as conceptualized and operationalized through the Francis Scale of Attitude toward Christianity (Francis, Lewis, Philipchalk, Brown, \& Lester, 1995), originally developed by Francis (1978a, 1978b). Francis argued that the affective or attitudinal dimension of religion offered a particularly fruitful basis for coordinating empirical enquiry into the correlates, antecedents and consequences of religiosity across the life span. The affective or attitudinal dimension appears particularly useful; drawing on the pioneering analysis of Fishbein and Ajzen (1975), Francis (1978a, 1978b) argued that attitudinal measures should focus on accessing the affective dimension of religiosity, in a way that is clearly distinguished from the cognitive dimension (concerned with beliefs) and from the behavioral dimension (concerned with practice). The affective dimension is able to transcend the divisions between denominational perspectives, while beliefs tend to polarize such divisions. The affective dimension is less likely to be distorted by personal and contextual factors, while practice tends to be subject to all kinds of personal or social constraints. Moreover, the affective dimension of religiosity can be accessed by instruments which can function in a comparatively stable manner over a wide age range. While the sophistication with which beliefs are formulated and tested clearly develops over the lifespan (e.g., see Fowler, 1981), attitudinal statements concerned with positive and negative affect can be formulated in ways which are equally acceptable during childhood, adolescence, and adulthood (Francis, 1989). The Francis measure of attitude toward Christianity is available both as a 24-item scale (Francis \& Stubbs, 1987; Francis, Lewis, Philipchalk, Brown, \& Lester, 1995), and as a short 7-item scale (Francis, 1993; Francis, Lewis, Philipchalk, Lester, \& Brown, 1995).

Recognizing the desirability of establishing comparable measures of the attitudinal dimension of religion across different religious traditions, Francis 
and colleagues initiated a program to produce a family of measures equivalent to the Francis Scale of Attitude toward Christianity, appropriate for other specific religions, including the Sahin-Francis Scale of Attitude toward Islam (Sahin \& Francis, 2002), the Katz-Francis Scale of Attitude toward Judaism (Francis \& Katz, 2007) and the Santosh-Francis Scale of Attitude toward Hinduism (Francis, Santosh, Robbins, \& Vij, 2008). To develop the Sahin-Francis Scale of Attitude toward Islam (Sahin \& Francis, 2002), the items of the Francis Scale of Attitude toward Christianity were carefully scrutinized and debated by several Muslim scholars until agreement was reached on 23 items which mapped closely onto the area assessed by the parent instrument. The psychometric properties of the instrument were assessed on 381 Muslim adolescents in England. Subsequently the instrument was tested among groups such as a sample of 1,199 Muslim adolescents in Kuwait (Francis, Sahin, \& Al-Ansari, 2006; Francis, Sahin, \& Al-Failakawi, 2008), a sample of 211 students in Malaysia (Tekke, Watson, İsmail, \& Chen, 2015), a sample of 729 students in Pakistan (Hamid, Robbins, Nadeem, \& Khan, 2016), and a sample of 250 teachers in Iran (Ghorbani, Watson, Zarei, \& Chen, 2017). In an independent initiative, Ok (2016) developed the Religious Attitude Scale (Islam) that had much in common with the principles underpinning the Francis family of attitudinal measures. This is an eight-item instrument designed to combine two items for each of four sub-measures characterized as cognition, emotion, behavior, and relationship with God. Indeed some of the items closely reflect the intention of items included in the original Francis measure.

\section{Personal happiness}

Robbins and Francis (1996) proposed establishing a set of studies exploring the connection between religion and happiness grounded in the measurement of personal happiness, as conceptualized and operationalized through the Oxford Happiness Inventory was developed by Michael Argyle and colleagues (Argyle \& Crossland, 1987; Argyle, Martin, \& Crossland, 1989). This operationalization of happiness embraced three components of the construct: the frequency and degree of positive affect or joy, the average level of satisfaction over a period, and the absence of negative feelings such as depression and anxiety. Working from this definition, they developed the Oxford Happiness Inventory for which they reported an internal reliability of .90 (Cronbach, 1951), and a 7-week testretest reliability of .78. The Oxford Happiness Inventory has also generated a small family of related measures, employing slightly different items in a different response format, including the Oxford Happiness Questionnaire and the Oxford Happiness Questionnaire Short-form (see Hills \& Argyle, 2002) and the Oxford Happiness Measure (see Elken, Francis, \& Robbins, 2010). 


\section{Controlling for personality}

Robbins and Francis (1996) proposed establishing a set of studies that took seriously the possibility of personality differences contaminating the bivariate association between religion and happiness, as conceptualized and operationalized through the three-dimensional model of personality (Eysenck \& Eysenck, 1991). The Eysenckian model maintains that the most adequate, economical, and efficient summary of individual differences is provided by three higher-order orthogonal dimensions defined by the high-scoring end of the three continua as extraversion, neuroticism, and psychoticism. The Eysenckian self-report measures also routinely include a Lie Scale. The consensus from this body of research is that the dimension of personality that predicts substantial individual differences in religion is psychoticism (see Francis, 1992), while the dimensions of personality that predict substantial differences in happiness are extraversion and neuroticism (see Francis, Brown, Lester, \& Philipchalk, 1998; Francis, 1999).

\section{Examining the evidence}

The program of research following from the recommendations made by Robbins and Francis (1996) began within a Christian or post-Christian context. Between 1996 and 2003, seven studies were published employing the Francis Scale of Attitude toward Christianity and the Oxford Happiness Inventory among a range of different groups; all reported a significant positive association between religion and happiness. The study groups were 360 first-year undergraduate students in Wales (Robbins \& Francis, 1996); 212 undergraduate students in the United States (Francis \& Lester, 1997); 295 participants, ranging in age from late teens to late seventies, recruited from groups attending a variety of courses and workshops on the psychology of religion (Francis \& Robbins, 2000); 994 15- to 16-year-old secondary school students (Francis, Jones, \& Wilcox, 2000); 496 members of the University of the Third Age (Francis, Jones, \& Wilcox, 2000); 456 undergraduate students in Wales (Francis, Jones, \& Wilcox, 2000); and 89 students in Wales (Francis, Robbins, \& White, 2003). Taken together these seven samples $(\mathrm{N}=360,212,295,995,456,496,89)$ demonstrated a consistent pattern of a significant positive correlation between religion and happiness based on employing the same instruments in different contexts. The scientific strategy of replication seemed to be bearing fruit, although further studies remain desirable.

The next stage of the program of research extended the replication studies beyond the Christian or post-Christian context. The first extension of the research was within a Jewish context in Israel using the Katz-Francis Scale of 
Attitude toward Judaism alongside the Oxford Happiness Inventory. Between 2002 and 2014, three studies reported a significant positive association between religion and happiness among students in Israel: 298 Hebrew-speaking female undergraduate students (Francis \& Katz, 2002); 203 Hebrew-speaking male undergraduate students (Francis, Katz, Yablon, \& Robbins, 2004); and 348 Hebrew-speaking female undergraduate students (Francis, Yablon, \& Robbins, 2014). Further replications are currently under way in Israel.

The second extension of the research was within an Islamic context in Turkey, using the Ok Religious Attitude Scale (Islam; Ok, 2016) alongside the Oxford Happiness Inventory. This study conducted among 348 students studying at a state university also found a significant positive association between religion and happiness (Francis, Ok, \& Robbins, 2017). The positive correlation between religion and happiness in an Islamic context demonstrated by the Ok Religious Attitude Scale (Islam) and the Oxford Happiness Inventory is consistent with the findings of Abdel-Khalek $(2007,2010)$ in Kuwait. In these two studies Abdel-Khalek employed single-item self-rating measures of religiosity and happiness in surveys conducted among 6,339 adolescents between the ages of 15 and 18 years, and 224 undergraduate students.

\section{Research question}

The present study is situated within the context of a serious replication project to explore the association between religion (drawing on the Francis family of measures of religious affect) and happiness (drawing on the Argyle family of measures of personal happiness) after taking into account individual differences in personality (drawing on the Eysenck three-dimensional model of personality).

The aim of the present study is to report a further replication in an Islamic context. This study differs from the first Islamic study reported by Francis, Ok, and Robbins (2017) in three ways that make an original contribution to knowledge: The first study was conducted in Turkey; this study is conducted in Malaysia. The first study employed the Ok Religious Attitude Scale (Islam); this study employs the Sahin-Francis Scale of Attitude toward Islam. Finally, in order to clarify the understanding of Islam in the present study, the analysis has been conducted among participants self-identifying as Sunni, as represented within the International Islamic University in Malaysia. 


\section{Method}

\section{Sample}

A sample of 189 students ( 41 men and 148 women) attending the International Islamic University in Kuala Lumpur, Malaysia, completed a short questionnaire as part of their coursework, across a range of courses such as educational psychology and counselling, and education curriculum and instruction. They were assured of complete confidentiality and anonymity and given the option not to participate in the project. All students attending the coursework session participated. The majority of the participants were between the ages of 20 and 24 years old $(\mathrm{N}=185)$, with 3 participants under the age of 20 , and 1 participant over the age of 24. All participants included in the following analyses selfidentified as Sunni Muslims. The majority $(\mathrm{N}=180)$ self-identified as Malay, with 5 from Indonesia, 2 from Thailand, 1 from India, and 1 from Turkey. The participants recorded a high level of religious commitment: $98 \%$ claimed to pray daily; $90 \%$ reported that they felt their life was being guided by God; $62 \%$ said that they recited the Qur'an daily, with a further 20\% doing so weekly; 32\% said that they gave to charity weekly, with a further $67 \%$ giving to charity with less frequency.

\section{Measures}

Since the International Islamic University uses English as the medium of instruction, the participants completed English-language versions of three measures: happiness was assessed by the Oxford Happiness Inventory; religiosity was assessed by the Sahin-Francis Scale of Attitude toward Islam; and personality was assessed by the short form of the Eysenck Personality Questionnaire Revised.

The Oxford Happiness Inventory (Argyle, Martin, \& Crossland, 1989) is a 29-item multiple choice instrument. Each item contains four options, constructed to reflect incremental steps defined as: unhappy or mildly depressed, a low level of happiness, a high level of happiness, and mania. The respondents are asked to 'pick out the one statement in each group which best describes the way you have been feeling over the past week, including today' An example item reads: 'I don't feel life is particularly rewarding' (unhappy or mildly depressed), 'I feel life is rewarding' (a low level of happiness), 'I feel that life is very rewarding' (a high level of happiness), and 'I feel that life is overflowing with rewards' (mania).

The Sahin-Francis Scale of Attitude toward Islam proposed by Sahin and Francis (2002), tested by Francis, Sahin, and Al-Ansari (2006) and commended by Abu-Raiya and Hill (2014) is a 23-item Likert type instrument focusing 
on the affective dimension of religion. Each item is rated on a five-point scale: agree strongly, agree, not certain, disagree, and disagree strongly.

The shortened form of the Eysenck Personality Questionnaire Revised (Eysenck, Eysenck, \& Barrett, 1985) is a 32-item instrument composed of four eight-item measures of extraversion, neuroticism, psychoticism, and a lie scale. Each item is assessed on a two-point scale: yes and no. Example items from the extraversion scale include: 'Are you a talkative person?' and 'Can you easily get some life into a rather dull party?' Example items from the neuroticism scale include: 'Does your mood often go up and down?' and 'Are you a worrier?' Example items from the psychoticism scale include: 'Do you prefer to go your own way rather than act by the rules?' and 'Do you enjoy co-operating with others?'. Example items from the lie scale include: 'Have you ever blamed someone for doing something you knew was really your fault?' and 'Have you ever taken advantage of someone?'

\section{Results}

Table 1 presents the scale properties of the Oxford Happiness Inventory, the Religious Attitude Scale (Islam), and the shortened form of the Eysenck Personality Questionnaire Revised. Apart from the psychoticism scale all measures achieve satisfactory levels of internal consistency reliability as demonstrated by the alpha coefficient (Cronbach, 1951). The weaker performance of the psychoticism scale is consistent with the recognized difficulties involved in operationalizing this construct (Francis, Brown, \& Philipchalk, 1992).

Table 2 presents the correlation coefficients between happiness, sex, religious attitude, extraversion, neuroticism, psychoticism, and lie scale. The two main findings from these data are: positive religious attitude is associated with high extraversion $(\mathrm{r}=.22, \mathrm{p}<.01)$ and with being female $(\mathrm{r}=.18, \mathrm{p}<.05)$; and that there is a small positive association between happiness and religiosity $(r=$ $.22, \mathrm{p}<.01)$.

Table 1. Scale properties

\begin{tabular}{lccrr}
\hline Measures & N & & \\
items & alpha & Mean & SD \\
\hline Oxford Happiness Inventory & 29 & .94 & 42.73 & 15.19 \\
Attitude toward Islam & 23 & .90 & 110.31 & 5.51 \\
Extraversion & 8 & .48 & 4.94 & 1.70 \\
Neuroticism & 8 & .72 & 5.34 & 2.16 \\
Psychoticism & 8 & .52 & 1.39 & 1.43 \\
Lie scale & 8 & .64 & 3.34 & 2.03 \\
\hline
\end{tabular}

Note: $N=189$ 
Table 2. Correlations

\begin{tabular}{lcccccc}
\hline Predictors & OHI & L & P & N & E & Rel \\
\hline Sex & $-.21^{\star \star}$ & .12 & $-.28^{\star \star \star}$ & .01 & -.02 & $.18^{\star}$ \\
Religious Attitude & $.22^{\star \star}$ & .13 & -.13 & -.01 & $.22^{\star \star}$ & \\
Extraversion (E) & $.28^{\star \star \star}$ & $-.15^{\star}$ & .02 & -.06 & & \\
Neuroticism (N) & -.10 & $-.30^{\star \star \star}$ & .06 & & & \\
Psychoticism (P) & $.21^{\star \star}$ & -.03 & & & & \\
Lie scale (L) & .06 & & & & & \\
\hline
\end{tabular}

Note: ${ }^{*}, p<.05 ;{ }^{* *}, p<.01 ;{ }^{* * *}, p<.001$

$N=189$

Table 3. Regression model

\begin{tabular}{llrrrrrl}
\hline & & \multicolumn{7}{c}{ Increase } & & \\
\cline { 3 - 6 } Predictors & $r^{2}$ & $r^{2}$ & $\mathrm{~F}$ & $p<$ & Beta & $t$ & $p<$ \\
\hline Sex & .00 & .00 & 0.1 & $\mathrm{NS}$ & -.00 & -.02 & NS \\
Extraversion (E) & .08 & .08 & 16.1 & .001 & .24 & 3.32 & .001 \\
Neuroticism (N) & .09 & .01 & 1.4 & NS & -.08 & -1.10 & NS \\
Psychoticism (P) & .13 & .04 & 8.5 & .01 & .23 & 3.34 & .001 \\
Lie scale (L) & .14 & .01 & 1.3 & NS & .05 & 0.67 & NS \\
Religious Attitude & .17 & .03 & 7.0 & .01 & .19 & 2.65 & .01 \\
\hline
\end{tabular}

Note: $N=189$

Table 3 takes the analysis one step further. In this hierarchical regression model, happiness stands as the dependent variable and the predictor variables were entered in the following fixed order: sex, extraversion, neuroticism, psychoticism, lie scale, and religious attitude. The main finding from these data is that, after sex and individual differences in personality have been taken into account, scores of attitude toward Islam provide a further small but statistically significant predictor of a happiness, demonstrating that religious people are happier people $(\beta=.19, p<.01)$.

\section{Conclusion}

The present study was situated within the context of a serious replication project initiated in the mid-1990s by Robbins and Francis (1996) designed to explore the association between religion and happiness. This set of studies drew on Francis's conceptualization and operationalization of the attitudinal dimension of religion as originally expressed through the Francis Scale of Attitude toward Christianity (see Francis, Lewis, Philipchalk, Brown, \& Lester, 1995) and subsequently developed through the Katz-Francis Scale of Attitude toward Judaism (Francis \& Katz, 2007) and the Sahin-Francis Scale of Attitude toward Islam (Sahin \& Francis, 2002). This set of studies also drew on Argyle's con- 
ceptualization and operationalization of happiness, principally as expressed through the Oxford Happiness Inventory (Argyle, Martin, \& Crossland, 1989).

The aim of the present study was to build on the work of Ok, Francis, and Robbins (2017) by undertaking a second survey within an Islamic context. This second study differed from the first study by being tested on a sample of Sunni Muslims in Malaysia. While the first study included secular as well as highly religious Muslims, the second study comprised highly religious participants. The core findings from the two studies conducted within Islamic contexts were, nonetheless, highly similar: both studies reported a significant positive correlation between religious affect and personal happiness as operationalized by the Francis concept of the attitudinal dimension of religion and by the notion of happiness captured by the Oxford Happiness Inventory.

Within the context of the replication project initiated by Robbins and Francis (1996), this is now the second study conducted within Islamic settings that has affirmed the positive association between religious affect and personal happiness. Within the broader context of research concerned with the association between religiosity and happiness using other self-rating scales of happiness and religiosity, the present result is consistent with the recent findings among Malaysian samples (e.g. Achour, Mohd Nor, Amel, Bin Seman, \& Mohd Yusoff, 2017) and congruent with previous findings on Sunni students across Muslim nations (e.g. Abdel-Khalek, 2012).

This finding is of relevance to the developing field of empirical theology within an Islamic context, as represented by research published by van der Tuin and Fumbo (2012), Ok and Eren (2013), Sterkens and Yusuf (2015), and Sterkens and Hadiwitanto (2016). This finding is also of relevance to the developing dialogue between an Islamic psychology of religion and the psychology of religion published within Jewish and Christian traditions as envisaged, for example, by Sahin and Francis (2002) and Tekke, Ismail, Adnan, and Othman (2015). In terms of positive psychology and psychological wellbeing among Muslim populations, the findings suggest that, alongside personality, positive religious affect is an indicator of higher levels of personal happiness and wellbeing.

\section{References}

Abdel-Khalek, A. M. (2007). Religiosity, happiness, health, and psychopathology in a probability sample of Muslim adolescents. Mental Health, Religion and Culture, 10, 571-583. https://doi.org/10.1080/13674670601034547

Abdel-Khalek, A. M. (2010). Quality of life, subjective wellbeing, and religiosity in Muslim college students. Quality of Life Research, 19, 1133-1143. https://doi. org/10.1007/s11136-010-9676-7

Abdel-Khalek, A. M. (2012). Associations between religiosity, mental health, and sub- 
jective wellbeing among Arabic samples from Egypt and Kuwait. Mental Health, Religion and Culture, 15, 741-758. https://doi.org/10.1080/13674676.2011.624502

Abu-Raiya, H., \& Hill, P. C. (2014). Appraising the state of measurement of Islamic religiousness. Psychology of Religion and Spirituality, 6, 22-32. https://doi.org/10.1037/ a0035082

Achour, M., Mohd Nor, M. R., Amel, B., Bin Seman, H. M., \& Mohd Yusoff, M. Y. Z. (2017). Religious commitment and its relation to happiness among Muslim students: The educational level as moderator. Journal of Religion and Health, 56, 1870-1889. doi 10.1007/s10943-017-0361-9

Argyle, M., \& Crossland, J. (1987). Dimensions of positive emotions. British Journal of Social Psychology, 26, 127-137. https://doi.org/10.1111/j.2044-8309.1987. tb00773.x

Argyle, M., Martin, M., \& Crossland, J. (1989). Happiness as a function of personality and social encounters. In J. P. Forgas and J. M. Innes (Eds.), Recent advances in social psychology: An international perspective (pp. 189-203). Amsterdam: Elsevier.

Atherton, J., Graham, E., \& Steedman, I. (2011). The practices of happiness: Political economy, religion and wellbeing. London: Routledge.

Cronbach, L. J. (1951). Coefficient alpha and the internal structure of tests. Psychometrika, 16, 297-334. https://doi.org/10.1007/BF02310555

Elken A, Francis, L. J., \& Robbins, M. (2010). Internal consistency reliability of the Estonian translation of the Oxford Happiness Measure: Contributing to positive psychology in Estonia. In E. E. Wells (Ed.) Psychological wellbeing (pp. 223-230). New York: Nova Science Publishers.

Eysenck, H. J., \& Eysenck, S. B. G. (1991). Manual of the Eysenck Personality Scales. London: Hodder and Stoughton.

Eysenck, S. B. G., Eysenck, H. J., \& Barrett, P. (1985). A revised version of the psychoticism scale. Personality and Individual Differences, 6, 21-29. https://doi. org/10.1016/0191-8869(85)90026-1

Fishbein, M., \& Ajzen, I. (1975). Belief, attitude, intention and behavior: An introduction to theory and research. Reading, MA: Addison-Wesley.

Fowler, J. W. (1981). Stages of faith: The psychology of human development and the quest for meaning. San Francisco: Harper and Row.

Fradera, A. (2015). When psychologists tried to replicate 100 previously published findings. The Psychologist, 28, 794-795.

Francis, L. J. (1978a). Attitude and longitude: A study in measurement. Character Potential, 8, 119-130.

Francis, L. J. (1978b). Measurement reapplied: Research into the child's attitude towards religion. British Journal of Religious Education, 1, 45-51. https://doi. org/10.1080/0141620780010202

Francis, L. J. (1989). Measuring attitude towards Christianity during childhood and adolescence. Personality and Individual Differences, 10, 695-698. https://doi. org/10.1016/0191-8869(89)90230-4

Francis, L. J. (1992). Is psychoticism really a dimension of personality fundamental to religiosity? Personality and Individual Differences, 13, 645-652. https://doi. org/10.1016/0191-8869(92)90235-H

Francis, L. J. (1993). Reliability and validity of a short scale of attitude towards Christianity among adults. Psychological Reports, 72, 615-618. https://doi.org/10.2466/ pr0.1993.72.2.615

Francis, L. J. (1999). Happiness is a thing called stable extraversion: A further examina- 
tion of the relationship between the Oxford Happiness Inventory and Eysenck's dimensional model of personality and gender. Personality and Individual Differences, 26, 5-11. https://doi.org/10.1016/S0191-8869(98)00185-8

Francis, L. J., Brown, L. B., Lester, D., \& Philipchalk, R. (1998). Happiness as stable extraversion: A cross-cultural examination of the reliability and validity of the $\mathrm{Ox}-$ ford Happiness Inventory among students in the UK, USA, Australia and Canada. Personality and Individual Differences, 24, 167-171. https://doi.org/10.1016/S01918869(97)00170-0

Francis, L. J., Brown, L. B., \& Philipchalk, R. (1992). The development of an abbreviated form of the Revised Eysenck Personality Questionnaire (EPQR-A): Its use among students in England, Canada, the USA and Australia. Personality and Individual Differences, 13, 443-449. https://doi.org/10.1016/0191-8869(92)90073-X

Francis, L. J., Jones, S. H., \& Wilcox, C. (2000). Religiosity and happiness: During adolescence, young adulthood and later life. Journal of Psychology and Christianity, 19, 245-257.

Francis, L. J., \& Katz, Y. J. (2002). Religiosity and happiness: A study among Israeli female undergraduates. Research in the Social Scientific Study of Religion, 13, 75-86.

Francis, L. J., \& Katz, Y. J. (2007). Measuring attitude toward Judaism: The internal consistency reliability of the Katz-Francis Scale of Attitude toward Judaism. Mental Health, Religion and Culture, 10, 309-324. https://doi.org/10.1080/13694670600668291

Francis, L. J., Katz, Y. J., Yablon, Y., \& Robbins, M. (2004). Religiosity, personality and happiness: A study among Israeli male undergraduates. Journal of Happiness Studies, 5, 315-333. https://doi.org/10.1023/B:JOHS.0000048460.35705.e8

Francis, L. J., \& Lester, D. (1997). Religion, personality and happiness. Journal of Contemporary Religion, 12, 81-86. https://doi.org/10.1080/13537909708580791

Francis, L. J., Lewis, J. M., Philipchalk, R., Brown, L. B., \& Lester, D. (1995). The internal consistency reliability and construct validity of the Francis Scale of Attitude toward Christianity (adult) among undergraduate students in the UK, USA, Australia and Canada. Personality and Individual Differences, 19, 949-953. https://doi. org/10.1016/S0191-8869(95)00131-X

Francis, L. J., Lewis, J. M., Philipchalk, R., Lester, D., \& Brown, L. B. (1995). Reliability and validity of a short scale of attitude toward Christianity among students in the UK, USA, Australia and Canada. Psychological Reports, 77, 431-434. https://doi. org/10.2466/pr0.1995.77.2.431

Francis, L. J., Ok, U., \& Robbins, M. (2017). Religion and happiness: A study among university students in Turkey. Journal of Religion and Health. 56, 1335-1347 https:// doi.org/10.1007/s10943-016-0189-8

Francis, L. J., \& Robbins, M. (2000). Religion and happiness: A study in empirical theology. Transpersonal Psychology Review, 4(2), 17-22.

Francis, L. J., Robbins, M., \& White, A. (2003). Correlation between religion and happiness: A replication. Psychological Reports, 92, 51-52. https://doi.org/10.2466/ pr0.2003.92.1.51

Francis, L. J., Sahin, A., \& Al-Ansari, E. (2006). The psychometric properties of the Sahin-Francis Scale of Attitude toward Islam among young adults in Kuwait. Muslim Educational Quarterly, 23, 69-82.

Francis, L. J., Sahin, A., \& Al-Failakawi, F. (2008). Psychometric properties of two Islamic measures among young adults in Kuwait: The Sahin-Francis Scale of Attitude toward Islam and the Sahin Index of Islamic Moral Values. Journal of Muslim Mental Health, 3, 9-24. https://doi.org/10.1080/15564900802035201 
Francis, L. J., Santosh, R., Robbins, M., \& Vij, S. (2008). Assessing attitude toward Hinduism: The Santosh-Francis Scale. Mental Health, Religion and Culture, 11, 609621. https://doi.org/10.1080/13674670701846469

Francis, L. J., \& Stubbs, M. T. (1987). Measuring attitudes towards Christianity: From childhood into adulthood. Personality and Individual Differences, 8, 741-743. https://doi.org/10.1016/0191-8869(87)90075-4

Francis, L. J., Yablon, Y. B., \& Robbins, M. (2014). Religion and happiness: A study among female undergraduate students in Israel. International Journal of Jewish Education Research, 7, 77-92.

Ghorbani, N., Watson, P. J., Zarei, A., \& Chen, Z. (2017). Muslim attitudes and spirituality: Relationships with Dark Triad and harmony control in Iranian teachers. Mental Health, Religion and Culture, 20, 20-30. https://doi.org/10.1080/1367467 6.2017.1320367.

Hamid, S. N., Robbins, M., Nadeem, T., \& Khan, Z. (2016). The Sahin-Francis Scale of Attitude toward Islam: A study among students in Pakistan. Journal of Empirical Theology, 29, 190-200. https://doi.org/10.1163/15709256-12341342

Hills, P., \& Argyle, M. (2002). The Oxford Happiness Questionnaire: A compact scale for the measurement of psychological well-being. Personality and Individual Differences, 33, 1073-1082. https://doi.org/10.1016/S0191-8869(01)00213-6

Ok, Ü. (2016). The Ok Religious Attitude Scale (Islam): Introducing an instrument originated in Turkish for international use. Journal of Beliefs and Values, 37, 55-67. https://doi.org/10.1080/13617672.2016.1141529

Ok, U., \& Eren, S. (2013). Attitudes towards human rights and religiosity: A case of Turkish adolescents. In J. A. van der Ven \& H-G. Ziebertz (Eds.), Human rights and the impact of religion (pp. 145-165). Leiden: Brill.

Robbins, M., \& Francis, L. J. (1996). Are religious people happier? A study among undergraduates. In L. J. Francis, W. K. Kay, \& W. S. Campbell (Eds.), Research in religious education (pp. 207-218). Leominster: Fowler Wright.

Sahin, A., \& Francis, L. J. (2002). Assessing attitude toward Islam among Muslim adolescents: The psychometric properties of the Sahin-Francis scale. Muslim Education Quarterly, 19(4), 35-47.

Sterkens, C., \& Hadiwitanto, H. (2016). Empirical models of the relationship between religion and state in Indonesia. In H.-G. Ziebertz \& E. H. Ballin (Eds.), Freedom of religion in the twenty-first century: A human rights perspective on the relation between politics and religion (pp. 162-206). Leiden: Brill.

Sterkens, C., \& Yusuf, M. (2015). Preferences for religious education and inter-group attitudes among Indonesian students. Journal of Empirical Theology, 28, 49-89. https://doi.org/10.1163/15709256-12341324

Tekke, M., Ismail, N. A. H., Adnan, M. A. M., \& Othman, N. (2015). Students' Islamic personality on Amanah: A structural modelling approach. Social Sciences \& $\mathrm{Hu}$ manities, 23, 1-10.

Tekke, M., Watson, P. J., İsmail, N. A. H., \& Chen Z. (2015). Muslim religious openness and Ilm: Relationships with Islamic religious reflection, religious schema, and religious commitments in Malaysia. Archive for the Psychology of Religion, 37, 295320. https://doi.org/10.1163/15736121-12341313

van der Tuin, L. W. J. M., \& Fumbo, C. D. (2012). Women rights and religion among Christian and Islamic students in Tanzania. In J. A. van der Ven \& H-G. Ziebertz (Eds.), Tensions within and between religions and human rights (pp. 203-222). Leiden: Brill. https://doi.org/10.1163/9789004218697_009 